\title{
Studi tentang Faktor-Faktor Penentu Customer Loyalty pada Grabfood: Investigasi atas Perceived Value, Customer Satisfaction, dan Switching Cost
}

\author{
Anna Rosaria Firdhiani ${ }^{1}$, Ari Setiyaningrum ${ }^{1}$ \\ ${ }^{1}$ Fakultas Ekonomi dan Bisnis, Universitas Katolik Atma Jaya, Jakarta, Indonesia
}

Info Article

History Article:

Submitted: 07 September 2020

Revised: 12 November 2020

Accepted: 25 November 2020

Keywords:

Perceived Value, Customer Satisfaction, Switching Cost Customer Loyalty
Abstrak

Penelitian ini dilakukan untuk menguji faktor-faktor penentu customer loyalty pada Grabfood yang mencakup perceived value, customer satisfaction dan switching cost. Penelitian ini juga menguji peran mediasi customer satisfaction pada pengaruh perceived value terhadap customer loyalty dan menguji peran moderasi switching cost pada pengaruh customer satisfaction terhadap customer loyalty. Metode pengambilan sampel di penelitian ini ialah non-probability sampling melalui teknik purposive sampling. Survei dilakukan dengan mendistribusikan kuesioner pada 160 responden yang sudah pernah menggunakan aplikasi Grabfood minimal sebanyak 3 kali. Data dianalisis menggunakan analisis mediasi moderasi Macro Process SPSS. Hasil penelitian menunjukkan bahwa perceived value dan customer satisfaction berpengaruh terhadap customer loyalty, perceived value berpengaruh terhadap customer satisfaction, customer satisfaction memediasi pengaruh perceived value terhadap customer loyalty, dan switching cost tidak memoderasi pengaruh customer satisfaction terhadap customer loyalty.

\section{Study on the Determinant of Customer Loyalty at Grabfood: The Investigation of Perceived Value, Customer Satisfaction, dan Switching Cost}

\begin{abstract}
This research was conducted to test the determining factors of customer loyalty on Grabfood which include perceived value, customer satisfaction and switching cost. This research also tests the mediating role of customer satisfaction on the influence of perceived value on customer loyalty and tests the moderation role of switching cost on the influence of customer satisfaction on customer loyalty. The sampling method in this study is nonprobability sampling through purposive sampling technique. The survey was conducted by distributing questionnaires to 160 respondents who had used the Grabfood application at least 3 times. The data is analyzed using macro process SPSS moderation mediation analysis. The results showed that perceived value and customer satisfaction affect customer loyalty, perceived value affects customer satisfaction, customer satisfaction mediates perceived value influence on customer loyalty, and switching cost does not moderate the influence of customer satisfaction on customer loyalty.
\end{abstract}

How to Cite: Firdhiani, A., R. \& Setiyaningrum, A. (2020). Studi tentang Faktor-Faktor Penentu Customer Loyalty pada Grabfood: Investigasi atas Perceived Value, Customer Satisfaction, dan Switching Cost. Ekonomi Bisnis, 25(2), 120-132 
Perkembangan teknologi informasi memberikan banyak dampak yang positif bagi sebagian besar masyarakat terutama masyarakat di kota besar. Jasa delivery makanan on-line saat ini telah menjadi salah satu kebutuhan bagi masyarakat yang tinggal di kota besar yang menyukai hal praktis dan serba instan. Selain itu, adanya pandemi Covid-19 yang terus meluas di hampir seluruh wilayah negara di dunia termasuk Indonesia sejak awal tahun 2020 membuat masyarakat banyak yang memilih untuk tidak keluar rumah demi alasan kesehatan dan keamanan sesuai arahan dari pemerintah. Penyebaran virus Covid-19 terus mengalami peningkatan yang cukup tinggi. Hal ini menyebabkan, perkantoran, pusat perbelanjaan ataupun kios-kios harus ditutup dan menjalankan operasionalnya secara on-line untuk meminimalkan penyebarluasan virus. Karenanya, jasa delivery makanan on-line menjadi sebuah pilihan bijaksana bagi sebagian besar masyarakat di tengah kondisi pandemi.

Perusahaan besar seperti Gojek dan Grab menangkap peluang ini melalui aplikasi delivery makanan on-line yaitu Gofood dan Grabfood. Hasil riset Nielsen menunjukkan bahwa Gofood dan Grabfood menjadi layanan pesan makanan on-line terfavorit di Indonesia (Prama, 2019). Jumlah pengguna Grabfood masih lebih sedikit dibandingkan dengan Gofood baik sebelum maupun selama pandemi. Sebelum ada pandemi Covid-19, jumlah pengguna aktif Grabfood selama tahun 2019 meningkat 173 persen dari tahun sebelumnya (Laraspati, 2020). Namun jumlah pengguna Grabfood masih lebih sedikit jika dibandingkan Gofood karena Gofood berhasil menguasai 75 persen dari pasar delivery makanan on-line di Indonesia (Prama, 2019). Pada masa pandemi Covid-19, meskipun terjadi peningkatan jumlah pengguna namun jumlah pengguna Grabfood hanya meningkat 4 persen saja (Kholisdinuka, 2020), sedangkan jumlah pengguna Gofood meningkat sebesar 20 persen (Zhafira, 2020). Hal ini menjadi masalah bagi Grabfood karena belum seberhasil pesaingnya dalam meningkatkan customer loyalty dan menambah jumlah pelanggan. Karenanya perlu untuk dilakukan penelitian mengenai faktor-faktor yang menentukan customer loyalty Grabfood.

Pada umumnya perusahaan terus berupaya mempertahankan customer loyalty karena biaya yang dibutuhkan untuk dapat menarik jumlah pelanggan baru lebih besar dibandingkan dengan biaya yang dibutuhkan untuk mempertahankan customer loyalty (Kotler \& Keller, 2016). Penelitian terdahulu menemukan bahwa customer loyalty ditentukan oleh sejumlah faktor diantaranya perceived value, customer satisfaction, dan switching cost (Aydin, Ozer, \& Arasil, 2005, 2005; Chen \& Tsai, 2008; El-Adly, 2019; Javed \& Cheema, 2017; Nikhashemi, Tarofder, Gaur \& Haque, 2016; Rahi \& Ghani, 2016; Thielemann, Ottenbacher, \& Harrington, 2018; Tsai, Tsai, \& Chang, 2010; Yang \& Peterson, 2004).

Penelitian terdahulu mengenai pengaruh perceived value terhadap customer loyalty masih menemukan hasil yang kontroversi. Di satu sisi, penelitian Chen \& Tsai (2008), Tsai et al. (2010), Nikhashemi et al. (2016), Javed \& Cheema (2017), dan Thielemann et al. (2018) menemukan bahwa perceived value memiliki pengaruh positif terhadap customer loyalty. Di sisi lain, penelitian Munhurrun, Seebaluck, \& Naidoo (2015) serta Howat \& Assaker (2013) menemukan bahwa perceived value tidak berpengaruh terhadap customer loyalty. Terkait dengan peran moderasi switching cost, Tsai et al. (2010) dan Stan et al. (2013) membuktikan bahwa switching cost memoderasi pengaruh customer satisfaction terhadap customer loyalty, sedangkan Yang \& Peterson (2004) menemukan bahwa switching cost tidak memoderasi pengaruh customer satisfaction terhadap customer loyalty.

Berdasarkan perbedaan hasil temuan tersebut, maka penelitian ini mencoba 
melengkapi penelitian terdahulu untuk mengkonfirmasi mengenai pengaruh perceived value terhadap customer loyalty pada konteks jasa delivery makanan on-line Grabfood dengan menguji customer satisfaction sebagai variabel mediasi dan switching cost sebagai variabel moderasi.

Switching cost dalam konteks penelitian ini merupakan suatu kondisi yang dirasakan konsumen apabila beralih ke penyedia jasa delivery on-line lain selain Grabfood sehingga memerlukan biaya yang sifatnya ekonomis seperti harga khusus bagi member dan biaya non ekonomis seperti faktor keamanan serta kemudahan penggunaan aplikasi. Sejauh ini peran mediasi customer satisfaction dan peran moderasi switching cost lebih banyak diteliti pada konteks jasa operator seluler serta jasa restoran dan belum diteliti pada konteks jasa delivery makanan on-line.

Perceived value dapat diartikan secara sempit dan luas. Perceived value dalam arti yang sempit dapat diartikan sebagai proses penukaran antara apa yang didapatkan untuk sesuatu yang diberikan. Perceived value secara luas dapat diartikan sebagai seluruh faktor baik secara kuantitatif maupun kualitatif, subjektif maupun objektif yang melengkapi pengalaman berberlanja (El-Adly \& Eid, 2016). Berdasarkan pengertian tersebut dapat disimpulkan bahwa perceived value merupakan evaluasi perbandingan antara benefit atau nilai yang didapat konsumen atas suatu produk atau jasa dengan sejumlah pengorbanan yang harus diberikan untuk mendapatkan produk atau jasa tersebut.

Customer satisfaction merupakan perasaan senang atau perasaan kecewa yang dialami seseorang setelah melakukan perbandingan persepsi atau kesan yang ada di benaknya terhadap kinerja aktual dari suatu produk dengan apa yang diharapkannya ( Setiyaningrum, Udaya, \& Efendi, 2015; Kotler \& Keller, 2016). Kepuasan dan ketidakpuasan mencerminkan persepsi dan sikap seseorang yang terbentuk berdasarkan pengalaman menggunakan atau mengkonsumsi produk/jasa di masa lalu dan selanjutnya dapat mempengaruhi intensi seseorang untuk membeli kembali produk/jasa tersebut di masa mendatang (Setiyaningrum, 2010). Kepuasan pelanggan merupakan unsur penting dalam pengiriman jasa karena pemahaman dan pemenuhan akan kebutuhan dan keinginan konsumen dapat meningkatkan pangsa pasar dari terbentuknya rutinitas (Setiyaningrum, 2010). Berdasarkan pengertian tersebut dapat disimpulkan bahwa customer satisfaction merupakan evaluasi perbandingan antara apa yang diharapkan konsumen terkait kinerja suatu produk atau jasa dengan kinerja aktual produk atau jasa tersebut.

Switching cost dapat diartikan sebagai sebuah pengorbanan atau penalti yang diberikan kepada konsumen karena telah melakukan perpindahan dari provider satu ke provider lainnya (Tsai et al., 2010). Switching cost juga mengacu pada biaya atas terjadinya perpindahan atau migrasi dari satu penyedia jasa tertentu ke penyedia jasa lainnya (Tsai et al., 2010). Menurut Dick \& Basu (1994), switching cost terbagi menjadi dua yaitu monetary switching dan nonmonetary switching. Monetary switching berupa monetary expenses dan nonmonetary berupa energi dan waktu. Berdasarkan pengertian tersebut dapat disimpulkan bahwa switching cost merupakan biaya yang ditanggung oleh konsumen karena melakukan perpindahan dari provider produk/jasa satu ke provider poduk/jasa lainnya.

Customer loyalty dapat diartikan sebagai komitmen yang dimiliki oleh buyer untuk tetap setia pada produk atau jasa serta pada merek atau organisasi secara konsisten untuk saat ini hingga di masa yang akan datang meskipun dalam situasi yang baru atau pada situasi yang tergolong sangat kompetitif yang mendorong pergantian pada produk lainnya (Flint et al., 2011). Berdasarkan pengertian tersebut customer loyalty mencerminkan 
sebuah komitmen yang dibangun oleh buyers terhadap penjual untuk terus membeli barang ataupun jasa yang ditawarkan pemasar dalam jangka waktu yang lama meskipun terdapat banyak pilihan lain yang tersedia.

Customer perceived value merupakan dasar fundamental dari seluruh kegiatan marketing (Yang dan Peterson, 2004). Perceived value dapat dimaknai sebagai penilaian secara keseluruhan mengenai kegunaan dari produk yang didasarkan atas persepsi mengenai benefit yang diterima dibandingkan dengan biaya yang dikeluarkan untuk suatu layanan (Chen \& Tsai, 2008; Tsai et al., 2010). Penelitan terdahulu menemukan bahwa customer perceived value memiliki pengaruh positif terhadap customer loyalty (Chen \& Tsai, 2008; Javed \& Cheema, 2017; Nikhashemi et al., 2016; Rahi \& Ghani, 2016; Thielemann et al., 2018; Tsai et al., 2010; Yang \& Peterson, 2004). Berdasarkan hal tersebut, penelitian ini menguji hipotesis pertama penelitian yang dirumuskan sebagai berikut:

\section{H1: perceived value berpengaruh terhadap customer loyalty.}

Woodruff (1997) mengemukakan bahwa seluruh penilaian mengenai produk atau jasa merupakan hasil dari berbagai pengalaman konsumsi yang dilakukan oleh pelanggan. Apabila respon pelanggan positif dan merasa puas terhadap layanan yang diberikan maka akan memberikan peluang lebih untuk mempertahankan pelanggan. Sejumlah peneliti sebelumnya membuktikan bahwa perceived value mempengaruhi customer satisfaction (Chen \& Tsai, 2008; Howat \& Assaker, 2013; Kungumapriya \& Malarmathi, 2018; Munhurrun et al., 2015; Simanjuntak, Putri, Yuliati, \& Sabri, 2020; Thielemann et al., 2018; Tsai et al., 2010; Yang \& Peterson, 2004). Atas dasar logika teoritis dan juga temuan empiris sebelumnya, peneliti mengajukan hipotesis kedua:

\section{H2: perceived value berpengaruh terhadap customer satisfaction.}

Satisfaction merupakan rangkuman dari seluruh pengalaman customer dalam menggunakan layanan (Li \& Petrick, 2010). Pengalaman dengan tingkat kepuasan yang tinggi akan berpengaruh langsung terhadap loyalty (Homburg, Hoyer \& Koschate, 2005). Reichheld \& Sasser (1990) mengemukakan bahwa customer yang puas terhadap layanan yang diberikan akan meningkatkan customer loyalty dan akan membuka peluang untuk melakukan repeat purchase di kemudian hari. Studi terdahulu menunjukkan bahwa customer satisfaction memiliki pengaruh positif terhadap customer loyalty (Aydin, Ozer, \& Arasil, 2005; El-Adly, 2019; Howat \& Assaker, 2013; Javed \& Cheema, 2017; Munhurrun, Seebaluck, \& Naidoo, 2015; Thielemann, et al., 2018; Tsai et al., 2010; Yang \& Peterson, 2004). Berdasarkan hal tersebut, penelitian ini akan menguji hipotesis ketiga:

\section{H3: customer satisfaction berpengaruh terhadap customer loyalty.}

Customer satisfaction diidentifikasi sebagai salah satu faktor yang dapat memediasi pengaruh perceived value terhadap customer loyalty. Dengan demikian Ketika konsumen merasakan perceived value yang tinggi dan merasa sangat puas atas produk/ jasa maka tentunya akan menghasilkan customer loyalty yang lebih tinggi. Penelitian sebelumnya membuktikan bahwa customer satisfaction memediasi pengaruh perceived value terhadap customer loyalty (Chen \& Tsai, 2008; Thielemann et al., 2018; Tsai et al., 2010). Atas dasar temuan empiris dan logika teoritis tersebut, peneliti merumuskan hipotesis keempat yang menguji pengaruh mediasi perceived value:

H4: customer satisfaction memediasi pengaruh perceived value terhadap customer loyalty.

Switching cost merupakan biaya yang dikenakan pada pelanggan yang melakukan perpindahan dari provider satu ke provider lain (Porter, 1998). Fornell (1992) mengemukakan bahwa hubungan antara customer satisfaction dan 
customer loyalty dipengaruhi oleh berbagai faktor yaitu tipe industri, switching cost dan perbedaan produk atau jasa yang ditawarkan. Studi terdahulu mengenai peran moderasi switching cost menemukan hasil yang bertentangan. Tsai et al. (2010) dan Stan et al. (2013) membuktikan bahwa switching cost memoderasi pengaruh customer satisfaction terhadap customer loyalty, sedangkan Yang \& Peterson (2004) serta Setiyaningrum (2010) tidak berhasil membuktikan bahwa switching cost memoderasi pengaruh customer satisfaction terhadap customer loyalty. Untuk mengkonfirmasi perbedaan hasil temuan studi terdahulu maka penelitian ini mengajukan hipotesis kelima, yakni:

\section{H5: switching cost memoderasi pengaruh} customer satisfaction terhadap customer loyalty.

\section{METODE}

Penelitian ini termasuk jenis penelitian kausalitas yang menguji pengaruh langsung perceived value terhadap customer loyalty dan pengaruh tidak langsung perceived value terhadap customer loyalty melalui mediasi customer satisfaction. Penelitian ini juga menguji peran moderasi switching cost pada pengaruh customer satisfaction terhadap customer loyalty. Model penelitian yang diuji di penelitian ini ditampilkan pada Gambar 1.

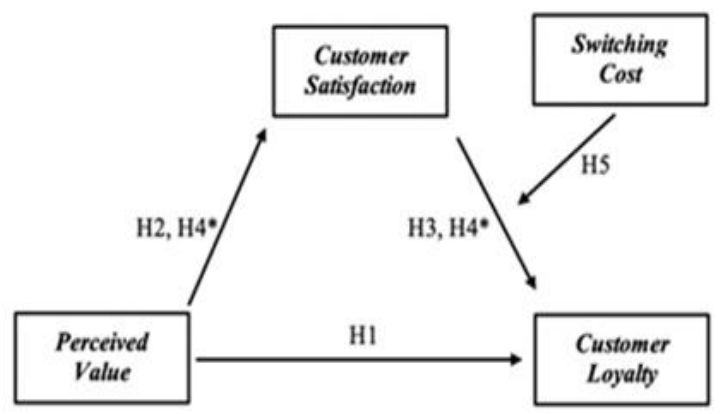

Keterangan: * merupakan uji mediasi

\section{Gambar 1. Model Penelitian}

Penelitian ini dilakukan menggunakan data primer yang didapatkan melalui survei dengan cara mendistribusikan kuesioner pada responden yang berlokasi di wilayah Jabodetabek (Jakarta, Bogor, Depok, Tangerang, Bekasi). Waktu pengumpulan data primer yaitu dari bulan Desember 2019 sampai dengan Mei 2020. Populasi dalam penelitian ini ialah semua orang di Jabodetabek yang pernah menggunakan jasa delivery makanan online melalui Grabfood. Sedangkan sampel pada penelitian ini ialah semua orang di Jabodetabek yang pernah menggunakan jasa delivery makanan online melalui Grabfood minimal 3 kali. Teknik sampling yang digunakan ialah non probability sampling melalui teknik purposive sampling. Kriteria responden di penelitian ini yaitu sudah pernah menggunakan aplikasi Grabfood lebih dari 3 kali dan berada di wilayah Jabodetabek. Jumlah total indikator akhir di penelitian ini adalah 22 butir sehingga jumlah sampel yang diambil adalah 160 responden. Jumlah 160 responden tersebut sudah sesuai dengan jumlah sampel minimal yang direkomendasikan Hair et al. (2010) yang mensyaratkan 5-10 kali jumlah indikator.

Sebelum kuesioner didistribusikan ke sampel besar, peneliti melakukan pretest pada 30 responden. Prestest mencakup uji validitas yang dilakukan menggunakan korelasi bivariate pearson dan uji reliabilitas. Instrumen penelitian dinyatakan valid apabila memiliki nilai korelasi pearson diatas 0,361 dan nilai signifikansi dibawah 0,05 (Ghozali, 2018). Instrumen penelitian dinyatakan reliabel apabila menghasilkan nilai cronbach alpha diatas 0,6 (Ghozali, 2018). Penelitian ini menguji model penelitian dengan variabel mediasi dan moderasi sehingga data penelitian dianalisis menggunakan macro process SPSS Hayes. Analisis data dengan macro process SPSS tidak mensyaratkan uji asumsi klasik regresi dan model yang tepat digunakan untuk menguji mediasi dan moderasi adalah model 14 (Hayes, 2013). 
HASIL

\section{Profil Responden}

Responden di penelitian ini terdiri atas 60 persen wanita dan 40 persen pria. Mayoritas responden penelitian berusia 19-26 tahun (84\%), tingkat pendidikan terakhir Sarjana $(81 \%)$, dan pekerjaan sebagai karyawan swasta (69\%).

\section{Hasil Pretest}

Hasil pretest instrumen penelitian pada 30 responden menunjukkan bahwa seluruh instrumen penelitian sudah valid dan reliabel. Hasil uji validitas awal menggunakan korelasi bivariate pearson menunjukkan bahwa dari 23 butir indikator, terdapat 1 indikator yang tidak valid dan indikator tersebut dikeluarkan dari analisis. Selanjutnya peneliti melakukan uji validitas ulang dengan menggunakan 22 indikator dan hasilnya menunjukkan bahwa semua indikator penelitian valid karena menghasilkan nilai signifikansi kurang dari 0,05 dan nilai korelasi pearson diatas 0,361. Uji reliabilitas menunjukkan bahwa instrumen penelitian sudah reliabel karena nilai cronbach alpha yang dihasilkan diatas 0,6. Variabel perceived value menghasilkan nilai cronbach alpha sebesar 0,602; variabel customer satisfaction menghasilkan nilai cronbach alpha sebesar 0,692; variabel switching cost menghasilkan nilai cronbach alpha sebesar 0,641; dan variabel customer loyalty menghasilkan nilai cronbach alpha sebesar 0,672.

\section{Hasil Analisis Data menggunakan Macro Process SPSS Hayes}

Penelitian ini mempunyai tujuan utama untuk menguji peran mediasi customer satisfaction pada pengaruh perceived value terhadap customer loyalty dan menguji peran moderasi switching cost pada pengaruh customer satisfaction terhadap customer loyalty. Model 14 di macro process SPSS digunakan untuk menguji model penelitian. Hasil uji macro process SPSS ditampilkan dalam Tabel 1 dan Tabel 2.

Tabel 1 menyajikan hasil pengujian pengaruh langsung variabel independen (perceived value) terhadap variabel dependen (customer loyalty) maupun pengaruh tidak langsung variabel independen (perceived value) terhadap variabel

Tabel 1. Hasil Pengujian Pengaruh Langsung dan Tidak Langsung Menggunakan Macro Process SPSS

\begin{tabular}{|c|c|c|c|c|c|}
\hline $\begin{array}{l}\text { Model : } 14 \\
\text { Y : CL } \\
\text { X : PV } \\
\text { M : CS } \\
\text { W : SC } \\
\text { Sample size: }\end{array}$ & & & & & \\
\hline \multicolumn{6}{|c|}{ Direct effect of $\mathrm{X}$ on $\mathrm{Y}$} \\
\hline Effect & se & $\mathrm{t}$ & $\mathrm{p}$ & LLCI & ULCI \\
\hline 0,409 & 0,099 & 4,146 & 0,000 & 0,214 & 0,603 \\
\hline \multicolumn{6}{|c|}{ Indirect effect: PV $->$ CS $->$ CL } \\
\hline SC & Effect & BootSE & $\begin{array}{l}\text { Boot } \\
\text { LLCI }\end{array}$ & $\begin{array}{l}\text { Boot } \\
\text { ULCI }\end{array}$ & \\
\hline$-3,354$ & 0,315 & 0,076 & 0,166 & 0,467 & \\
\hline 0,000 & 0,303 & 0,063 & 0,184 & 0,431 & \\
\hline 3,354 & 0,290 & 0,084 & 0,134 & 0,458 & \\
\hline \multicolumn{6}{|c|}{ Index of moderated mediation } \\
\hline & Index & $\begin{array}{c}\text { Boot } \\
\text { SE }\end{array}$ & $\begin{array}{l}\text { Boot } \\
\text { LLCI }\end{array}$ & $\begin{array}{l}\text { Boot } \\
\text { ULCI }\end{array}$ & \\
\hline SC & $-0,004$ & 0,015 & $-0,033$ & 0,026 & \\
\hline
\end{tabular}

Sumber: Output Olahan data oleh Peneliti (2020) 
dependen (customer loyalty) melalui mediasi customer satisfaction.

Berdasarkan hasil pengujian pengaruh langsung di Tabel 1, perceived value ditemukan berpengaruh terhadap customer loyalty. Hal ini dapat ditunjukkan melalui nilai signifikansi 0,000 serta nilai LLCI $(0,214)$ dan ULCI $(0,603)$ yang melewati nilai nol. Dengan demikian H1 yang menyatakan perceived value berpengaruh terhadap customer loyalty diterima.

Hasil uji pengaruh tidak langsung di Tabel 1 menunjukkan bahwa perceived value berpengaruh tidak langsung terhadap customer loyalty melalui mediasi customer satisfaction yang dilihat dari nilai BootLLCI $(-0,033)$ dan BootULCI $(0,026)$ yang melewati nilai nol.
Karenanya, $\mathrm{H} 4$ yang menyatakan bahwa customer satisfaction memediasi pengaruh perceived value terhadap customer loyalty diterima.

Tabel 2 menyajikan hasil uji pengaruh variabel independen (perceived value) terhadap variabel mediasi (customer satisfaction), hasil uji pengaruh variabel mediasi (customer satisfaction) terhadap variabel dependen (customer loyalty), dan hasil uji variabel moderasi (switching cost) pada pengaruh variabel mediasi (customer satisfaction) terhadap variabel dependen (customer loyalty).

Hasil uji di Tabel 2 menunjukkan bahwa perceived value memiliki pengaruh terhadap customer satisfaction. Hal ini ditunjukkan dari nilai signifikansi 0,000 serta nilai LLCI $(0,419)$ dan ULCI $(0,721)$ yang melewati nilai nol. Karena itu,

Tabel 2. Hasil Uji Mediasi dan Moderasi menggunakan Macro Process SPSS

\begin{tabular}{|c|c|c|c|c|c|c|}
\hline \multicolumn{7}{|l|}{ Model : 14} \\
\hline \multicolumn{7}{|l|}{$\mathrm{Y}: \mathrm{CL}$} \\
\hline \multicolumn{7}{|l|}{$\mathrm{X}: \mathrm{PV}$} \\
\hline \multicolumn{7}{|l|}{$\mathrm{M}: \mathrm{CS}$} \\
\hline \multicolumn{7}{|l|}{$\mathrm{W}: \mathrm{SC}$} \\
\hline \multicolumn{7}{|c|}{ Sample size : 160} \\
\hline \multicolumn{7}{|c|}{ Outcome variable: CS } \\
\hline \multicolumn{7}{|c|}{ Model Summary } \\
\hline $\mathrm{R}$ & R-Square & MSE & $\mathrm{F}$ & df1 & df2 & $\mathrm{p}$ \\
\hline 0,544 & 0,502 & 4,276 & 55,554 & 1,000 & 158,00 & 0,000 \\
\hline \multicolumn{7}{|l|}{ Model } \\
\hline & Coeff & se & $\mathrm{t}$ & $\mathrm{p}$ & LLCI & ULCI \\
\hline Constant & $-12,085$ & 1,681 & $-7,188$ & 0,000 & $-15,406$ & $-8,764$ \\
\hline PV & 0,570 & 0,076 & 7,453 & 0,000 & 0,419 & 0,721 \\
\hline \multicolumn{7}{|c|}{ Outcome variable: CL } \\
\hline \multicolumn{7}{|c|}{ Model Summary } \\
\hline $\mathrm{R}$ & R-Square & MSE & $\mathrm{F}$ & df1 & df2 & $\mathrm{p}$ \\
\hline 0,757 & 0,573 & 4,980 & 55,349 & 4,000 & 155,000 & 0,000 \\
\hline \multicolumn{7}{|c|}{ Model } \\
\hline & Coeff & se & $\mathrm{t}$ & $\mathrm{p}$ & LLCI & ULCI \\
\hline Constant & 16,160 & 2,079 & 7,773 & 0,000 & 12,053 & 20,267 \\
\hline PV & 0,409 & 0,099 & 4,146 & 0,000 & 0,214 & 0,603 \\
\hline SC & 0,531 & 0,098 & 5,438 & 0,000 & 0,338 & 0,724 \\
\hline CS & 0,263 & 0,090 & 2,921 & 0,004 & 0,085 & 0,442 \\
\hline Int_1 & $-0,007$ & 0,027 & $-0,242$ & 0,809 & $-0,061$ & 0,047 \\
\hline
\end{tabular}

Sumber: Output Olahan data oleh Peneliti (2020) 
Hipotesis kedua (H2) yang menyatakan bahwa perceived value berpengaruh terhadap customer satisfaction diterima. Berdasarkan Tabel 2 dapat dilihat bahwa customer satisfaction berpengaruh terhadap customer loyalty dan hal ini ditunjukkan dari nilai signifikansi 0,004 serta nilai LLCI $(0,085)$ dan ULCI $(0,442)$ yang melewati nilai nol. Karenanya, H3 yang menyatakan bahwa customer satisfaction berpengaruh terhadap customer loyalty diterima.

Tabel 2 juga menunjukkan bahwa hasil uji moderasi menemukan bahwa switching cost tidak memoderasi pengaruh customer satisfaction terhadap customer loyalty. Hal ini bisa ditunjukkan melalui nilai signifikansi Int_1 sebesar 0,809 serta nilai LLCI $(-0,061)$ dan ULCI $(0,047)$ yang melewati nilai nol. Dengan demikian, H5 yang menyatakan bahwa switching cost memoderasi pengaruh customer satisfaction terhadap customer loyalty ditolak.

\section{PEMBAHASAN}

Penelitian ini menemukan beberapa temuan. Pertama, perceived value ditemukan berpengaruh terhadap variabel customer loyalty. Hasil dalam penelitian ini secara tegas mengkonfirmasi penelitian yang sudah dilakukan sebelumnya oleh Chen \& Tsai (2008) yang menemukan bahwa perceived value berpengaruh positif pada customer loyalty. Selain itu, hasil penelitian ini juga sejalan dengan penelitian Yang \& Peterson (2004), Rahi \& Ghani (2016), Nikhashemi et al. (2016), Javed \& Cheema (2017), dan Thielemann et al. (2018) yang juga menemukan bahwa perceived value berpengaruh terhadap customer loyalty.

Temuan ini mengartikan bahwa apabila Grabfood ingin meningkatkan customer loyalty, maka penyedia jasa tersebut harus dapat memastikan bahwa pelanggan menerima jasa yang diberikan dengan baik dan benar, sehingga benefit atau manfaat dari jasa tersebut benar-benar dirasakan oleh pelanggan tersebut. Hal ini tentunya akan lebih baik lagi apabila harga dan kualitas jasa yang ditawarkan sangat sesuai dengan kebutuhan pelanggan. Maka konsistensi layanan dan kualitas jasa yang diberikan Grabfood harus memiliki standar yang jelas. Sehingga, pelayanan yang diterima oleh pelanggan tetap sama satu dengan yang lain. Nilai tambah dari Grabfood juga dapat dilakukan dengan memberikan promo atau penawaran menarik bagi pelanggan. Promo dapat berupa pengurangan biaya administrasi, upgrade layanan dengan biaya yang sama, ataupun potongan untuk biaya pengiriman. Apabila pelanggan telah merasakan manfaat positif dari jasa delivery makanan Grabfood, maka nantinya pelanggan akan berkeinginan untuk merekomendasikan jasa tersebut ataupun berkeinginan untuk menggunakan Grabfood kembali, bahkan apabila loyalitas sudah terbangun, pelanggan Grabfood dapat tetap menggunakan Grabfood walaupun terdapat pesaing dengan harga yang lebih murah.

Kedua, penelitian ini menemukan bahwa perceived value berpengaruh terhadap customer satisfaction. Hasil dari penelitian ini sejalan atau sesuai dengan hasil penelitian sebelumnya yang pernah dilakukan oleh Chen \& Tsai (2008), Howat \& Assaker (2013), Kungumapriya \& Malarmathi (2018), Thielemann et al. (2018), dan Simanjuntak et al. (2020) yang juga membuktikan bahwa perceived value berpengaruh terhadap customer satisfaction.

Hasil ini mengindikasikan bahwa apabila Grabfood ingin meningkatkan tingkat kepuasan pelanggan, maka Grabfood harus memperhatikan dan meningkatkan benefit atau manfaat yang akan diterima oleh pengguna Grabfood tersebut. Grabfood dapat meningkatkan manfaat yang diterima pelanggan dengan cara memberikan jasa yang ditawarkan dengan baik dan benar kepada pelanggan. Hal ini dapat didukung dengan menawarkan harga atau biaya yang lebih menarik apabila dibandingkan 
dengan penyedia jasa delivery makanan/minuman online lainnya baik harga makanan/minuman maupun order fee makanan/minuman yang lebih murah. Selain itu, Grabfood juga dapat menawarkan berbagai promosi yang dapat digunakan dengan mudah oleh pelanggan misalnya potongan biaya jasa antar ataupun dapat berupa layanan gratis, promo bundling product. Hal ini dapat didukung juga dengan kerjasama dengan merchant-merchant yang bergabung dengan Grabfood. Grabfood juga dapat mengutamakan waktu dan usaha yang akan digunakan pelanggan untuk menerima layanan jasa ini. Hal ini dapat dilakukan dengan memberikan informasi secara berkala mengenai proses dan tahapan yang harus dilakukan untuk dapat menggunakan Grabfood, serta informasi secara realtime mengenai estimasi makanan atau minuman yang dipesan dapat sampai ke customer. Dengan demikian pelanggan dapat memahami dan menerima adanya proses yang membutuhkan waktu untuk dapat menerima makanan atau minuman yang dipesan. Apabila hal-hal tersebut telah dilakukan maka apabila jasa yang ditawarkan sesuai ataupun melebihi harapan pengguna Grabfood, maka pengguna Grabfood akan merasa puas.

Ketiga, hasil penelitian ini telah berhasil membuktikan secara jelas bahwa customer satisfaction berpengaruh terhadap customer loyalty. Temuan penelitian ini memperkuat hasil penelitian Tsai et al. (2010), Munhurrun et al. (2015), Javed dan Cheema (2017), Thielemann et al. (2018), Stan et al. (2013), dan El-Adly (2019) yang juga menemukan bahwa customer satisfaction berpengaruh terhadap customer loyalty.

Hasil temuan penelitian ini menjelaskan bahwa apabila Grabfood ingin meningkatkan loyalitas pelanggannya, maka Grabfood harus meningkatkan juga tingkat kepuasan dari pelanggan. Hal ini dapat dilakukan dengan berbagai hal. Salah satu subjek yang berperan penting dalam layanan jasa ialah pegawai dari
Grabfood. Pegawai ini menjadi pihak yang berinteraksi dan berhubungan secara langsung dengan pelanggan karena bertugas mengirimkan atau memberikan makanan atau minuman yang dipesan ke pelanggan. Pada konteks Grabfood, pegawai yang dimaksud ialah driver. Sikap, etika dan cara berpakaian, bahasa dari pegawai ini merupakan salah satu kunci untuk membuat pelanggan puas dengan layanan yang diberikan. Maka, hal ini perlu diperhatikan oleh Grabfood. Apabila diperlukan, para driver dapat diberikan pelatihan mengenai sikap, etika, cara berpakaian untuk mendukung proses penyampaian jasa tersebut ke customer. SOP juga dapat dibuat untuk mendukung hal tersebut. Selain itu, Grabfood juga harus dapat menjamin layanan yang diberikan untuk selalu memuaskan dan sesuai dengan harapan pelanggan. Disamping itu, Grabfood juga dapat mempermudah dan memperjelas langkah-langkah ataupun persyaratan yang harus dipersiapkan pelanggan sebelum menerima jasa tersebut. Upaya ini bisa dijalankan dengan cara memberikan gambar tahapan proses sehingga pelanggan dapat mengetahui dan mengikuti alur kerja serta persyaratan yang diperlukan dengan mudah. Selain itu, Grabfood juga dapat mempersiapkan media-media pendukung pemberikan jasa tersebut, misalnya software aplikasi yang canggih, mudah digunakan dan diakses oleh pelanggan. Sehingga meminimalisir adanya crash pada aplikasi tersebut dan dapat langsung digunakan oleh pelanggan. Selain itu, tingkat customer satisfaction juga harus dievaluasi sebagai masukan bagi Grabfood apakah pelayanan Grabfood telah sesuai dengan apa yang diharapkan pelanggan atau tidak. Maka, setelah makanan atau minuman telah diberikan, diperlukan adanya tahap penilaian untuk mengetahui penilaian pelanggan terhadap jasa delivery makanan atau minuman yang dipesan. Adanya kolom komentar disediakan untuk memberikan ruang bagi pelanggan dalam menyuarakan pendapatnya. 
Apabila terdapat komentar ataupun saran terhadap jasa antar makanan/ minuman yang tidak sesuai dengan harapan pelanggan maka pihak customer care dapat menindaklanjuti keluhan tersebut. Dengan demikian loyalitas pelanggan terhadap Grabfood dapat terbangun.

Keempat, penelitian ini menemukan bahwa customer satisfaction memediasi pengaruh perceived value terhadap customer loyalty. Hasil pada penelitian sesuai dengan hasil temuan Chen \& Tsai (2008), Tsai et al. (2010), dan Thielemann et al. (2018) yang juga membuktikan bahwa pengaruh customer perceived value terhadap customer loyalty dapat dimediasi oleh customer satisfaction.

Hasil penelitian ini menjelaskan bahwa untuk meningkatkan customer loyalty, Grabfood tidak hanya harus memberikan jasa delivery makanan/minuman dengan baik dan benar agar manfaat dan benefit dari Grabfood dirasakan benar oleh pelanggan. Namun, Grabfood harus dapat memastikan bahwa pelanggan merasa puas dengan jasa yang diberikan. Pealanggan yang telah merasa puas atas layanan yang diberikan Grabfood cenderung akan loyal terhadap Grabfood dan menggunakan kembali jasa tersebut atau bahkan merekomendasikan jasa tersebut pada orang lain. Grabfood dapat melakukan berbagai hal untuk tetap menjamin pelayanan yang diberikan ke pelanggan. Hal ini dapat dilakukan Grabfood misalnya dengan cara memberikan reward bagi driver yang selalu mendapatkan bintang 5 dari pelanggan atau reward bagi driver yang dapat mengantarkan pesanan sesuai dengan estimasi waktu pengantaran. Cara ini akan memotivasi driver untuk terus berusaha memberikan layanan yang terbaik pada pelanggan dan pada akhirnya pelanggan akan semakin loyal pada Grabfood.

Kelima, penelitian ini tidak berhasil membuktikan bahwa switching cost memoderasi pengaruh customer satisfaction terhadap customer loyalty. Di satu sisi, temuan ini sejalan dengan penelitian Yang \& Peterson (2004) dan
Setiyaningrum (2010) yang menemukan bahwa pengaruh customer satisfaction terhadap customer loyalty tidak dimoderasi oleh switching cost. Namun di sisi lain, temuan ini bertentangan dengan penelitian Tsai et al. (2010) dan Stan et al. (2013) yang berhasil membuktikan bahwa switching cost memoderasi pengaruh customer satisfaction terhadap customer loyalty.

Switching cost menggambarkan biaya baik finansial atau non finansial yang ditanggung oleh konsumen saat memutuskan untuk berpindah atau melakukan migrasi dari satu provider ke provider lain. Dalam konteks Grabfood, switching cost tidak terbukti memoderasi pengaruh customer satisfaction terhadap customer loyalty. Artinya, loyalitas pelanggan untuk terus menggunakan Grabfood sepenuhnya ditentukan oleh kepuasan yang dirasakan konsumen pada layanan yang diberikan Grabfood. Switching cost ditemukan tidak memoderasi karena dalam hal ini konsumen menilai untuk berpindah dari Grabfood ke provider delivery makanan lain hanya membutuhkan biaya, waktu, dan usaha yang minimal. Dengan demikian seharusnya Grabfood fokus pada value dari jasa yang akan diberikan pada pelanggan dan berusaha untuk terus membuat pelanggan merasa puas terhadap jasa yang diberikan. Apabila pelanggan sudah merasa kecewa dan tidak puas atas jasa atau layanan yang diberikan, maka pelanggan akan tetap memilih untuk berpindah ke penyedia jasa delivery makanan atau minuman lain tanpa mementingkan switching cost.

Selain itu diketahui bahwa persaingan dengan kompetitor utama Grabfood menjadi salah satu faktor penting yang juga harus lebih diperhatikan. Sekarang ini, kompetitor juga berlomba-lomba untuk memberikan value ataupun manfaat baik dari sisi jasa, pelayanan, bahkan harga ataupun promosi yang ditawarkan. Dari hasil penelitian ini terlihat bahwa meskipun Grabfood menerapkan switching cost dalam layanannya, ternyata hal ini belum mampu 
membuat pengguna berpikir dua kali untuk tetap menggunakan Grabfood karena apabila customer melakukan switching provider di aplikasi selain Grabfood, pelanggan tetap dapat dengan bebas melakukan perpindahan tersebut tanpa harus memikirkan switching cost yang diterapkan Grabfood. Karenanya, pada penelitian ini penggunaan switching cost bukan merupakan jawaban untuk meningkatkan customer satisfaction terhadap customer loyalty pada konteks jasa delivery makanan.

\section{SIMPULAN DAN SARAN}

Penelitian ini menyimpulkan bahwa dalam konteks jasa delivery makanan Grabfood, perceived value ditemukan berpengaruh langsung terhadap customer loyalty dan berpengaruh tidak langsung melalui mediasi customer satisfaction. Selain itu, hasil uji moderasi menunjukkan bahwa switcbing cost tidak memoderasi pengaruh customer satisfaction terhadap customer loyalty.

Saran praktis yang dapat direkomendasikan bagi Grabfood didasarkan hasil temuan penelitian yaitu untuk membangun customer loyalty, Grabfood sebaiknya memfokuskan strategi pemasarannya untuk meningkatkan perceived value dan customer satisfaction. Perceived value dapat ditingkatkan dengan cara menawarkan lebih banyak promo misalnya promo bundling makanan atau minuman yang dipesan melalui Grabfood, promo potongan biaya ongkos kirim, dan promo potongan harga makanan atau minuman. Disamping itu, Grabfood perlu bekerja sama penyedia uang digital lainnya selain OVO agar pelanggan memiliki pilihan metode pembayaran lainnya. Customer satisfaction dapat ditingkatkan melalui upaya untuk menjaga konsistensi layanan yang diberikan pada pelanggan dengan cara memonitor pelayanan yang diberikan secara rutin. Grabfood dapat memberikan pelatihan mengenai service excellence bagi para driver yang berinteraksi langsung dengan pelanggan dan menerapkan program reward bagi para driver untuk memotivasi driver agar bekerja lebih baik dalam melayani pelanggan. Selain itu, Grabfood dapat memberlakukan sistem potongan biaya untuk pemesanan selanjutnya misalnya berupa potongan ongkos kirim dan potongan harga makanan atau minuman apabila customer memberikan testimoni dan sharing pengalaman positif setelah menggunakan layanan Grabfood.

Penelitian ini masih memiliki keterbatasan dan karenanya peneliti memberikan sejumlah saran bagi penelitian selanjutnya. Pertama, penelitian selanjutnya dapat meneliti variabel mediasi lain seperti customer trust dan variabel moderasi lain seperti involvement. Kedua, penelitian selanjutnya dapat meneliti jasa lain yang ditawarkan perusahaan Grab misalnya Grabbike, Grabcar, Grabsend, dan Grabhealth. Ketiga, penelitian selanjutnya dapat mempertimbangkan untuk menguji model penelitian di konteks setting yang berbeda misalnya e-commerce atau online travel agency yang merupakan penyedia jasa berbasis online.

\section{DAFTAR RUJUKAN}

Aydin, S., Ozer, G., \& Arasil, O. (2005). Customer loyalty and the effect of switching costs as a moderator variable-A case in the turkish mobile phone market. Journal of Marketing Intelligence \& Planning, 23(1), $89-103$.

Chen, C., \& Tsai, M. (2008). Perceived value, satisfaction, and loyalty of tv travel product shopping: Involvement as moderator. Journal of Tourism Management, 29, 11661171.

Dick, A. S., \& Basu, K. (1994). Customer Loyalty: Toward an Integrated Conceptual Framework. Journal of the Academy of Marketing Science, 22(2), 99-113.

El-Adly, M. I. (2019). Modelling the relationship 
between hotel perceived value, customer satisfaction, and customer loyalty. Journal of Retailing and Consumer Service, 50, 322-332.

El-Adly, M. I., \& Eid, R. (2016). An empirical study of the relationship between shopping environment, customer perceived value, satisfaction, and loyalty in the UAE malls context. Journal of Retailing and Consumer Services, 31, 217-227.

Flint, D. J., Blocker, C. P., \& Boutin, P. J. (2011). Customer value anticipation, customer satisfaction and loyalty: an empirical examination. Journal of Industrial Marketing Management, 40, 219-230.

Fornell, C. (1992). A national customer satisfaction barometer: The Swedish experience. Journal of Marketing, 56(1), 6-21.

Ghozali, I. (2018). Aplikasi Analisis Multivariate dengan program IBM SPSS 25 (9th ed.). Semarang: Badan Penerbit Universitas Diponegoro.

Hair, J. F. J., Black, W. C., Babin, B. J., \& Anderson, R. E. (2010). Multivariate Data Analysis (7th ed.). New Jersey: Prentice Hall, Inc.

Hayes, A. F. (2013). Introduction to mediation, moderation and conditional process analysis: a regression-based approach. New York: Guilford Press.

Homburg, C., Hoyer, W. D., \& Koschate, N. (2005). Customers' Reactions to Price Increases: Do Customer Satisfaction and Perceived Motive Fairness Matter? Journal of the Academy of Marketing Science, 69, 84-96.

Howat, G., \& Assaker, G. (2013). The hierarchical effects of perceived quality on perceived value, satisfaction and loyalty: Empirical result from public, outdoor aquatic centres in Australia. Journal of Sport Management Review, 16, 268-284.

Javed, F., \& Cheema, S. (2017). Customer satisfaction and customer perceived value and its impact on customer loyalty: the mediational role of customer relationship management. The Journal of Internet Banking and Commerce, 22(S8), 1-14.

Kholisdinuka, A. (2020). Transaksi grabfood naik selama pandemi corona, ini 3 menu terlarisnya. https://inet.detik.com/cyberlife/d-

5005211/transaksi-grabfood-naik-selamapandemi-corona-ini-3-menu-terlarisnya

Kotler, P., \& Keller, K. L. (2016). Marketing Management (15th Ed.). New Jersey: Prentice-Hall, Inc.

Kungumapriya, A., \& Malarmathi, K. (2018). The Impact of Service Quality, Perceived Value Customer Satisfaction in Calculative Commitment and Customer Loyalty Chain in India Mobile Telephone Sector. IOSR Journal of Business and Management (IOSRJBM), 20(5), 72-82.

Laraspati, A. (2020). Selama 2019, Pengguna Aktif GrabFood Meningkat bingga 173\%. https://inet.detik.com/cyberlife/d4854537/selama-2019-pengguna-aktifgrabfood-meningkat-hingga-173

Li, X., \& Petrick, J. F. (2010). Towards an integrative model of loyalty formation: The role of quality and value. Leisure Sciences, 32(3), 201-221.

Munhurrun, R. P., Seebaluck, V. N., \& Naidoo, P. (2015). Examining the structural relationships of destination image, perceived value, tourist satisfaction and loyalty: case of Mauritius. Procedia-Social and Behavioral Sciences, 175, 252-259.

Nikhashemi, S. R., Tarofder, A. K., Gaur, S. S., \& Haque, A. (2016). The effect of customers perceived value of retail store on relationship between store attribute and customer brand loyalty: some insight from Malaysia. Procedia-Economics and Finance, 37, 432-438.

Porter, M. (1998). Clusters and the new economics of competition. Harvard Business Review, 76(6), 77-90. 
Prama, N. (2019). Data Nielsen Gofood Sukses Jadi Layanan Pesan Makanan Online Terpopuler. https://nextren.grid.id/read/011863265/d ata-nielsen-gofood-sukses-jadi-layananpesan-makanan-onlineterpopuler?page $=$ all

Rahi, S., \& Ghani, M. A. (2016). Internet Banking, Customer Perceived Value and Loyalty: The Role of Switching Cost. Journal of Accounting \& Marketing, 5(4), 1-7.

Reichheld, F. F., \& Sasser, E. (1990). Zero Defections: Quality Comes to Services. Harvard Business Review, 68, 105-111.

Setiyaningrum, A. (2010). Analisis Kepuasan Pelanggan, Kepercayaan dan Loyalitas Pelanggan: Peran Variabel Pemoderasi Switching Cost. Jurnal Manajemen \& Bisnis, 9, 237-252.

Setiyaningrum, A., Udaya, J., \& Efendi. (2015). Prinsip-Prinsip Pemasaran Plus Tren Terkini Pemasaran Global, Pemasaran Jasa, Green Marketing, Entrepreneurial Marketing, EMarketing. Yogyakarta: Penerbit Andi.

Simanjuntak, M., Putri, N. E., Yuliati, L. N., \& Sabri, M. F. (2020). Enhancing customer retention using customer relationship management approach in car loan business. Cogent Business \& Management, 7(1), 1738200.

Stan, V., Caemmerer, B., \& Cattan-Jallet, R. (2013). Customer Loyalty Development: The Role of Switching Cost. The Journal of Applied Business Research, 29(5), 1541-1554.

Thielemann, V. M., Ottenbacher, M. C., \& J., H. R. (2018). Antecedents and consequences of perceived customer value in the restaurant industry a preliminary test of holistic model. International Hospitality Review, 32, 26-45.

Tsai, M.-T., Tsai, C.-L., \& Chang, H.-C. (2010). The effect of customer value, customer satisfaction and switching cost on customer loyalty: an empirical study of hypermarket in Taiwan. . . Journal of Social Behaviour and Personality, 38, 729740.

Wooddruff, R. B. (1997). Customer value: The next source for competitive advantage. Journal of the Academy of Marketing Science, 25(2), 139-153.

Yang, Z., \& Peterson, R. T. (2004). Customer perceived value, satisfaction, and loyalty: the role of switching cost. Journal Psychology \& Marketing, 21(10), 799-822.

Zhafira, A. (2020). Gofood catat peningkatan transaksi 20 persen pada masa pandemi. https://www.antaranews.com/berita/1579982 /gofood-catat-peningkatan-transaksi-20persen-pada-masa-pandemi 